\title{
Disease and Diagnosis
}

\section{Evaluation of Estrogen Receptor- $\alpha$ Gene (T/C) Polymorphism in Patients With Leiomyoma Compared to Healthy Individuals}

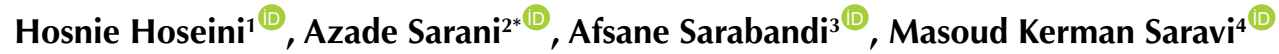 \\ 'Department of Laboratory Sciences, Zahedan Branch, Islamic Azad University, Zahedan, Iran. \\ ${ }^{2}$ Department of Midwifery, Faculty of Medical Sciences, Zahedan Branch, Islamic Azad University, Zahedan, Iran. \\ ${ }^{3}$ Department of Nursing, Islamic Azad University, Zahedan Branch, Zahedan, Iran. \\ ${ }^{4}$ Health Clinical Sciences Research Center, Zahedan Branch, Islamic Azad University, Zahedan, Iran.
}

\begin{abstract}
Background: Leiomyoma as one of the most prevalent tumors in women occurs at the same time of reproductive age and its causes are still unknown. Hormone therapy is one of the common treatments for this disease. Estrogen hormone through its receptor, which is called ER $\alpha$, plays an effective role in the treatment of leiomyoma. Single nucleotide polymorphisms (SNPs) are effective in the diagnosis, treatment, and prognosis of many diseases and tumors. In this regard, the current study investigated the estrogen receptor gene polymorphisms of ER $\alpha$ in women with leiomyoma in Sistan and Baluchestan province, Zahedan and then compared them with healthy individuals.

Materials and Methods: Overall, 150 women with leiomyoma were sampled and their DNA was isolated as well. In addition, 150 samples were taken from healthy individuals as the control group. The polymerase chain reaction-restriction fragment length polymorphism (PCR-RFLP) method and Pvull were used to study gene polymorphisms.

Results: The results showed a significant relationship between ER $\alpha$ gene polymorphism and leiomyoma.

Conclusion: Accordingly, this gene polymorphism can be considered as a marker for prognosis in leiomyoma in the population of Iranian women in Zahedan, Sistan and Baluchestan province.

Keywords: ER $\alpha$, Pvu II enzyme, Leiomyoma, SNP
\end{abstract}

*Correspondence to

Azade Sarani,

Department of Midwifery, Faculty of Medical Sciences, Zahedan Branch, Islamic Azad University, Zahedan, Iran.

Tel: +989376595977, Email: saraniazade@gmail. com

Received: May 4, 2021, Accepted: June 19, 2021, ePublished: June 28, 2021

\section{Introduction}

Leiomyoma is a common tumor in women of childbearing age and occurs in women over the age of 30. The causes of leiomyoma are unknown (1), but it is a common tumor in women of reproductive age and its prevalence is between $20 \%$ and $50 \%$ in women $<30$ years. Although little is known about the disease pathogenesis, research has shown that factors such as angiogenesis and interactions with hormonal effects on uterine cells have an impact on its progression (2). A DNA repair system is needed to maintain the genetic system of tissues. If the efficiency of this system decreases, the sensitivity to tissue tumorigenesis represents an increase. In addition, the restoration system plays an important role in protecting the genome against cancer-causing agents. In this system, gene polymorphisms have a major role in modulating genotoxic effects $(3,4)$ while having no role in diseases and cancers. However, polymorphism studies are effective in diagnosing risk factors for many diseases.
Single nucleotide polymorphisms (SNPs) often do not alter the level of gene transcription. Mutated alleles in SNPs can serve as a functional marker of a gene. Although polymorphism studies on multifactorial diseases such as leiomyoma are difficult due to uncertainty about the traits of the involved genes in the disease, they are needed for understanding the pathogenesis of the disease $(5,6)$. Hormonal changes leading to angiogenesis appear to be effective in the development of the disease, and leiomyoma is also associated with the effects of steroid hormones and paracrine and autocrine functions. Estrogen is the most important hormone that is involved in leiomyoma, and factors such as cytokines, growth factors, and DNA mutations cause the neoplastic myometrium to be converted to leiomyoma. The dysfunction of tumor suppressor genes effectively contributes to the development of tumors, and the gene repair system is effective in maintaining the optimal genetic function of tissues, reducing the efficiency of this system and 
leading to tumorigenesis $(7,8)$. Gene polymorphisms affect tumorigenic and genotoxic mechanisms that are not directly related to the disease but are effective as prognostic factors for tumors and diseases. SNPs fail to alter the level of gene transcription and can be out of balance with other unknown polymorphisms, causing susceptibility and pathogenicity. Thus, the genetic studies of multifactorial diseases such as leiomyoma are difficult $(9,10)$. To identify and understand the pathogenesis of leiomyoma, the study of SNPs is of particular importance $(11,12)$. In this case-control study, the SNPs of leiomyoma for the prognostic markers of the disease in women with leiomyoma were evaluated and then compared with healthy individuals.

\section{Materials and Methods \\ Study Population \\ Sampling}

The present case-control study included 150 women with leiomyoma and 150 healthy women referring to the Obstetrics and Gynecology Unit of Ali Ibn Abi Taleb hospital in Zahedan, Sistan and Baluchestan province. For these people, a complete clinical examination and definitive diagnosis were performed by laparoscopic ultrasound scan by a gynecologist. Then, 2 mL of peripheral blood was taken from the subjects for research. Accurate information and clinical records regarding menstruation, gestational age, use of contraceptives were also taken from the individuals. Before participating in the study, informed consent for research use was obtained from all patients, and all tests were performed in accordance with the guidelines of ethical medical research.

\section{Primers Designing}

Estrogen receptor $(E R)$ a gene sequences obtained from the NCBI and target using primers were designed by AlleleID software, version 7.5 (Premier Biosoft International, Palo Alto, CA). Later, designed and approved primers by OligoAnalyzer 3 in the NCBI database underwent analysis.

\section{DNA Extraction and Genotyping}

The genomic DNA of lymphoma patients and healthy controls was extracted from peripheral blood using the standard salting-out method describing elsewhere and stored at $-20^{\circ} \mathrm{C}$ until use. The polymerase chain reactionrestriction fragment length polymorphism (PCR-RFLP) method was performed to detect the genotypes of the ER $\alpha$ gene polymorphism. To this end, one selected polymorphism gene was amplified with specific primers listed in Table 1. The PCR was prepared using Ampliqon universal PCR master mix $(12.5 \mu \mathrm{L})$ by adding $1 \mu \mathrm{L}$ of genomic DNA, $0.5 \mu \mathrm{L}$ of each primer, and $10.5 \mu \mathrm{L}$ of nuclease-free water. Subsequently, the PCR products were digested with desired restriction enzymes (Fermentas) according to the manufacturer's instruction and analyzed by agarose gel electrophoresis (Table 1).

\section{Statistical Analysis}

The SPSS statistical software (version 21) was used for all statistical analyses. The chi-square test was applied to compare the expected and observed frequencies of categorical variables. The odds ratio was employed to assess the strength of the association of the genotype and allele frequency and the risk of the disease occurrence. A $P<0.05$ was considered statistically significant.

\section{Results}

A total of 300 patients were recruited in this study, including 150 leiomyoma patients and 150 healthy controls. The mean age of leiomyoma patients and the healthy controls was $35.14 \pm 16.1$ and $54.7 \pm 0.2$ years, respectively. No significant difference was observed in age distribution between the leiomyoma patients and the control group $(P<0.2)$.

\section{Association Between ER a Gene Polymorphism and Leiomyoma}

Table 2 provides the frequencies of genotypes and the alleles of all SNPs in leiomyoma patients and healthy controls. The genotype distribution of ER $\alpha \mathrm{C} / \mathrm{T}$ was CC: 50\%, CT: $30 \%$, and TT: $20 \%$, as well as CC: $40 \%$, CT: $54 \%$, and TT: $7 \%$ in leiomyoma patients and healthy controls, respectively. In the ER $\alpha$ polymorphism, the TT genotype showed an elevated level compared to the control group (TT: $\mathrm{OR}=2.03,95 \% \mathrm{CI}=0.59-4.19, P=0.3$ ). Our analysis also showed the significance of this difference.

\section{Discussion}

Endometriosis, which is a benign disorder, is highly common in women of childbearing age $(13,14)$. Further, it is a histological type of endometrial atrium that is found in extrauterine tissues, unlike fibroids that occur in the uterine wall $(15,16)$. The role of hormone

Table 1. Primer Sets and Related Restriction Enzymes Used for ER $\alpha$ SNP Analysis by the PCR-RLFP Method

\begin{tabular}{|c|c|c|c|}
\hline Polymorphism & Primer Sequence $\left(5^{`}->3^{\prime}\right)$ & Restriction Enzyme & Fragment (bp) \\
\hline$E R(\alpha)$ & $\begin{array}{l}\text { F: CCGCACGAGGGACAATA } \\
\text { R: TCTCTCGCCACTGGAAATC }\end{array}$ & Pvull, & $\begin{array}{l}\text { CC: } 306 \\
\text { TC: } 306+140+74 \\
\text { TT: } 140+74\end{array}$ \\
\hline
\end{tabular}

Note. SNP: Single nucleotide polymorphisms; ER: Estrogen receptor; PCR-RLFP: Polymerase chain reaction-restriction fragment length polymorphism. 
Table 2. The Frequencies of the Genotypes and Alleles of All SNPs in Leiomyoma Patients and Healthy Controls

\begin{tabular}{|c|c|c|c|c|}
\hline Polymorphisms & Case No. $(\%)$ & Control No. (\%) & OR $(95 \% \mathrm{Cl})$ & $P$ Value \\
\hline \multicolumn{5}{|l|}{ ER $\alpha$} \\
\hline $\mathrm{CC}$ & $84(50)$ & $48(40)$ & 1.00 & - \\
\hline СТ & $46(30)$ & $87(53)$ & $0.47(0.25-0.87)$ & 0.022 \\
\hline TT & $20(20)$ & $15(7)$ & $2.03(0.59-4.19)$ & 0.03 \\
\hline
\end{tabular}

Note. SNP: Single nucleotide polymorphisms; OR: Odds ratio; Cl: Confidence interval; ER; Estrogen receptor.

receptors is considered as an appropriate therapeutic response in the pathogenesis of leiomyoma. Research has shown that some hormone receptors at ectopic sites in the endometrial tissue contribute to the development of leiomyoma, and play the role of gene polymorphisms, growth factors, angiogenic factors, and cell cycle control genes in the development of leiomyoma and demographic pathology $(17,18)$. Many factors effective in the initiation and growth of leiomyoma in women. This demographic pathology has not been thoroughly studied due to the genetic susceptibility of Iranian women, but evidence confirms the relationship between single nucleotide genetic polymorphisms, hormone receptors, and cytokines with leiomyoma. SNP is one of the most diverse sequences in human genome DNA, and more than 1.4 million SNPs have been identified in the human genome $(19,20)$. Considering that SNPs can be rapidly analyzed in diseases, evaluation of the related disease has been considered by researchers. In leiomyoma, the evaluation of SNP markers is also considered in the analysis of the causes of this disease. The Medline database provides many studies on the correlation or non-correlation of gene polymorphisms with a variety of diseases including leiomyoma. In this regard, Howell RJ et al showed that the incidence of homozygosity CC in patients with leiomyoma is lower compared to healthy individuals (21). The results of our research demonstrated that the TT genotype has an elevated level compared to the control group. For example, some studies identified an association between androgen receptor gene polymorphism as a risk factor for leiomyoma in Iranian women (22, 23). Other studies confirmed an association between ER $\alpha$ gene polymorphisms and individual disorders. This polymorphism has shown conflicting results in endometriosis among different ethnic populations (24, 25). Allele $C$, for example, has been extremely effective in Caucasian, Greek, and Taiwanese women while having no connection with the German female population $(26,27)$. There are several polymorphisms in the ER $\alpha$ gene that are related to different gene alleles in the development of leiomyoma in women. In these studies, the restriction enzyme PvuII has been introduced as an agent for the identification of the ER $\alpha$ gene, which has the potential to identify the $\mathrm{T}$ allele, which is in the development of leiomyoma. The result of our study revealed that after analysis, the T allele is effective in the SNP of the ER $\alpha$ gene in the development of leiomyoma. The results of Kitawaki et al, Massart et al, and Wang et al represented that allele $\mathrm{C}$ is effective in the incidence of leiomyoma (28-30), which contradicts the results of our research. Based on the findings of studies on Caucasian, Italian, and German women, there was no association between alleles $\mathrm{C}$ and $\mathrm{T}$ ) and leiomyoma $(30,31)$. Neuss $\mathrm{K}$ et al also reported that the $\mathrm{T}$ allele was associated with endometriosis and fibroids in Asian Taiwanese women (32), which is consistent with the results of our study.

\section{Conclusion}

In this study, it was shown that the $E R \alpha \mathrm{C}$ allele increases the risk factor for leiomyoma in the Iranian female population, which can be effective as a prognostic factor in the diagnosis and treatment of leiomyoma. Finally, to obtain better results, it is recommended that future studies evaluate more polymorphisms in different ethnic populations.

\section{Conflict of Interest Disclosures}

The authors declare that they have no conflict of interests.

\section{Acknowledgments}

We would like to acknowledge Dr. Masoud Saravi, Dr. Hosnie Hoseini, and Dr. Afsane Sarabandi Ghaleno for their financial support. Thanks are due to the management and staff of Ali Ibn Abi Taleb Hospital Research Centre, Zahedan, Sistan and Baluchestan province for providing the clinical samples of the subjects enrolled in this study.

\section{Ethical Statement}

The current study was approved by the Ethics Committee of Ali Ibn Abi Talib hospital in the Affiliated Hospital of Zahedan Medical University. Before the operation, informed consent forms were signed by all patients after a detailed explanation of the therapeutic procedure. The study was conducted according to the guideline for the case series. (Ethical code: IR.IAU.ZAH. REC.1400.010)

\section{Authors' Contributions}

All authors contributed to data collection and wrote the manuscript. MS and $\mathrm{HH}$ conceived the structure of the manuscript and revised the manuscript. $\mathrm{HH}$ and AS made the figures and tables. HH, MS, and AS drafted the initial manuscript. All authors read the manuscript, approved the current manuscript for publication, attested that they substantially contributed to the current work, and disclosed that 
there was no writing assistance. All authors read and approved the final manuscript.

\section{Founding/Support}

Since the article is extracted from a research project, academic research project code is 141157718 .

\section{Informed Consent}

Written informed consent for publication was obtained from all participants.

\section{References}

1. Miura S, Khan KN, Kitajima M, Hiraki K, Moriyama S, Masuzaki H, et al. Differential infiltration of macrophages and prostaglandin production by different uterine leiomyomas. Hum Reprod. 2006;21(10):2545-54. doi: 10.1093/humrep/del205.

2. Hsieh YY, Chang CC, Bau DT, Tsai FJ, Tsai CH, Chen CP. The p21 codon $31^{\star} \mathrm{C}$ - and DRD2 codon $313^{\star} \mathrm{T}$-related genotypes/alleles, but not XRCC1 codon 399, hOGG1 codon 326, and DRD1-48 polymorphisms, are correlated with the presence of leiomyoma. Fertil Steril. 2009;91(3):869-877. doi:10.1016/j.fertnstert.2007.07.1328

3. Kim MR, Park DW, Lee JH, Choi DS, Hwang KJ, Ryu HS, et al. Progesterone-dependent release of transforming growth factor-beta1 from epithelial cells enhances the endometrial decidualization by turning on the Smad signalling in stromal cells. Mol Hum Reprod. 2005;11(11):801-8. doi: 10.1093/molehr/gah240.

4. Jacob F, Ries F, Dicato M. Genomic imprinting and its relevance for oncology. Biomed Pharmacother. 1993;47(4):127-9.

5. Di Lieto A, De Falco M, Pollio F, Mansueto G, Salvatore G, Somma P, et al. Clinical response, vascular change, and angiogenesis in gonadotropin-releasing hormone analogue-treated women with uterine myomas. J Soc Gynecol Investig. 2005;12(2):123-8. doi: 10.1016/j. jsgi.2004.10.008.

6. Strawn EY Jr, Novy MJ, Burry KA, Bethea CL. Insulinlike growth factor I promotes leiomyoma cell growth in vitro. Am J Obstet Gynecol. 1995;172(6):1837-44. doi: 10.1016/0002-9378(95)91420-x.

7. Vu TH, Yballe C, Boonyanit S, Hoffman AR. Insulinlike growth factor II in uterine smooth-muscle tumors: maintenance of genomic imprinting in leiomyomata and loss of imprinting in leiomyosarcomata. J Clin Endocrinol Metab. 1995;80(5):1670-6. doi: 10.1210/jcem.80.5.7745016.

8. Sharara FI, Nieman LK. Growth hormone receptor messenger ribonucleic acid expression in leiomyoma and surrounding myometrium. Am J Obstet Gynecol. 1995;173(3 Pt 1):814-9. doi: 10.1016/0002-9378(95)903461.

9. Ghahary A, Murphy LJ. Uterine insulin-like growth factor-I receptors: regulation by estrogen and variation throughout the estrous cycle. Endocrinology. 1989;125(2):597-604. doi: 10.1210/endo-125-2-597.

10. Magri KA, Benedict MR, Ewton DZ, Florini JR. Negative feedback regulation of insulin-like growth factor-II gene expression in differentiating myoblasts in vitro. Endocrinology. 1994;135(1):53-62. doi: 10.1210/ endo.135.1.8013391.

11. Friedman AJ, Rein MS, Pandian MR, Barbieri RL. Fasting serum growth hormone and insulin-like growth factor-I and -II concentrations in women with leiomyomata uteri treated with leuprolide acetate or placebo. Fertil Steril. 1990;53(2):250-3. doi: 10.1016/s0015-0282(16)53276-2.

12. Tommola P, Pekonen F, Rutanen EM. Binding of epidermal growth factor and insulin-like growth factor I in human myometrium and leiomyomata. Obstet Gynecol. 1989;74(4):658-62.

13. Kauppila A, Vierikko P, Isotalo H, Rönnberg L, Vihko R. Cytosol estrogen and progestin receptor concentrations and 17 beta-hydroxysteroid dehydrogenase activities in the endometrium and endometriotic tissue. Effects of hormonal treatment. Acta Obstet Gynecol Scand Suppl. 1984;123:45-9. doi: 10.3109/00016348409156981.

14. Maruo T, Ohara N, Wang J, Matsuo H. Sex steroidal regulation of uterine leiomyoma growth and apoptosis. Hum Reprod Update. 2004;10(3):207-20. doi: 10.1093/ humupd/dmh019.

15. Solomon LA, Schimp VL, Ali-Fehmi R, Diamond MP, Munkarah AR. Clinical update of smooth muscle tumors of the uterus. J Minim Invasive Gynecol. 2005;12(5):401-8. doi: 10.1016/j.jmig.2005.05.022.

16. Koninckx PR, Ide P, Vandenbroucke W, Brosens IA. New aspects of the pathophysiology of endometriosis and associated infertility. J Reprod Med. 1980;24(6):257-60.

17. Cramer DW, Wilson E, Stillman RJ, Berger MJ, Belisle S, Schiff I, et al. The relation of endometriosis to menstrual characteristics, smoking, and exercise. JAMA. 1986;255(14):1904-8.

18. Chiaffarino F, Parazzini F, La Vecchia C, Ricci E, Crosignani PG. Oral contraceptive use and benign gynecologic conditions. A review. Contraception. 1998;57(1):11-8. doi: 10.1016/s0010-7824(97)00201-1.

19. Flake GP, Andersen J, Dixon D. Etiology and pathogenesis of uterine leiomyomas: a review. Environ Health Perspect. 2003;111(8):1037-54. doi: 10.1289/ehp.5787.

20. Bergqvist A, Fernö M. Oestrogen and progesterone receptors in endometriotic tissue and endometrium: comparison of different cycle phases and ages. Hum Reprod. 1993;8(12):2211-7. doi: 10.1093/oxfordjournals. humrep.a138005.

21. Howell RJ, Dowsett M, Edmonds DK. Oestrogen and progesterone receptors in endometriosis: heterogeneity of different sites. Hum Reprod. 1994;9(9):1752-8. doi: 10.1093/oxfordjournals.humrep.a138788.

22. Jones RK, Bulmer JN, Searle RF. Immunohistochemical characterization of proliferation, oestrogen receptor and progesterone receptor expression in endometriosis: comparison of eutopic and ectopic endometrium with normal cycling endometrium. Hum Reprod. 1995;10(12):3272-9. doi: 10.1093/oxfordjournals.humrep. a135901.

23. Brandenberger AW, Lebovic DI, Tee MK, Ryan IP, Tseng JF, Jaffe RB, et al. Oestrogen receptor (ER)-alpha and ERbeta isoforms in normal endometrial and endometriosisderived stromal cells. Mol Hum Reprod. 1999;5(7):651-5. doi: 10.1093/molehr/5.7.651.

24. Kovács KA, Oszter A, Göcze PM, Környei JL, Szabó I. 
Comparative analysis of cyclin D1 and oestrogen receptor (alpha and beta) levels in human leiomyoma and adjacent myometrium. Mol Hum Reprod. 2001;7(11):1085-91. doi: 10.1093/molehr/7.11.1085.

25. Wieser F, Schneeberger C, Tong D, Tempfer C, Huber JC, Wenzl R. PROGINS receptor gene polymorphism is associated with endometriosis. Fertil Steril. 2002;77(2):30912. doi: 10.1016/s0015-0282(01)02984-3.

26. Hsieh YY, Wang YK, Chang CC, Lin CS. Estrogen receptor alpha-351 $\mathrm{XbaI}^{\star} \mathrm{G}$ and $-397 \mathrm{PvuII}^{\star} \mathrm{C}$-related genotypes and alleles are associated with higher susceptibilities of endometriosis and leiomyoma. Mol Hum Reprod. 2007;13(2):117-22. doi: 10.1093/molehr/gal099.

27. Georgiou I, Syrrou M, Bouba I, Dalkalitsis N, Paschopoulos M, Navrozoglou I, et al. Association of estrogen receptor gene polymorphisms with endometriosis. Fertil Steril. 1999;72(1):164-6. doi: 10.1016/s0015-0282(99)00198-3.

28. Kitawaki J, Obayashi H, Ishihara H, Koshiba H, Kusuki I, Kado N, et al. Oestrogen receptor-alpha gene polymorphism is associated with endometriosis, adenomyosis and leiomyomata. Hum Reprod. 2001;16(1):51-5. doi: 10.1093/ humrep/16.1.51.

29. Massart F, Becherini L, Marini F, Noci I, Piciocchi L, Del Monte F, et al. Analysis of estrogen receptor (ERalpha and ERbeta) and progesterone receptor (PR) polymorphisms in uterine leiomyomas. Med Sci Monit. 2003;9(1):BR25-30.

30. Wang Z, Yoshida S, Negoro K, Kennedy S, Barlow D, Maruo T. Polymorphisms in the estrogen receptor beta gene but not estrogen receptor alpha gene affect the risk of developing endometriosis in a Japanese population. Fertil Steril. 2004;81(6):1650-6. doi: 10.1016/j.fertnstert.2004.02.094.

31. Al-Hendy A, Salama SA. Ethnic distribution of estrogen receptor-alpha polymorphism is associated with a higher prevalence of uterine leiomyomas in black Americans. Fertil Steril. 2006;86(3):686-93. doi: 10.1016/j. fertnstert.2006.01.052.

32. Neuss K, Elling D, Cascorbi I, Lueftner D. Association between breast cancer and estrogen receptor gene polymorphism PVU II. J Clinical Oncol. 2006;24(18 Suppl):643. doi: 10.1200/jco.2006.24.18_suppl.643. 